\title{
Laboratory studies of the flow rates of debris-laden ice
}

\author{
Tim H. JAGKA,${ }^{1,2}$ Shavawn DONOGHUE, ${ }^{1}$ Jun LI, ${ }^{1,2 *}$ William F. BUDD, ${ }^{1}$ \\ Ross M. ANDERSON ${ }^{3}$ \\ ${ }^{1}$ Antartic CRC and ${ }^{2}$ Australian Antarctic Division, Private Bag 80, Hobart, Tasmania 7001, Australia \\ E-mail:jo.jacka@aad.gov.au \\ ${ }^{3}$ La Trobe University, P.O. Box 199, Bendigo,Victoria 3552, Australia
}

\begin{abstract}
Ice-sheet basal ice is warmer than that above because of the heat from the Earth's interior. The stresses acting on the basal ice are greatest. In addition, the basal ice often contains debris consisting of silt and small stones picked up from the rock over which the ice flows. Because the base is the warmest part of an ice sheet and the stress there is greatest, flow rates in the basal ice are large and often contribute most of the ice movement. It is therefore important, for accurate modelling of the ice sheets, to know whether the debris within the basal ice enhances or retards the flow of the ice. In this paper, we describe laboratory deformation tests in uniaxial compression and in simple shear, on sand-laden ice. We find no significant dependence of flow rate on sand content (up to $15 \%$ volume) in the stress range $0.13-0.5 \mathrm{MPa}$ and temperature range -0.02 to $-18.0^{\circ} \mathrm{C}$. Further work needs to include laboratory tests on debris-laden ice extracted from the polar ice sheets. This work is underway.
\end{abstract}

\section{BAGKGROUND}

There is interest in the flow properties of debris-laden ice because it is widespread near the base of ice sheets and glaciers. The deep cores extracted from near the bed in Greenland (Camp Century, Dye 3, GRIP and GISP2) and Antarctica (Byrd, Dome Summit South) all contain debrisladen ice up to many metres from the bottom. In ice sheets the basal layers generally have relatively high shear stress and temperature compared to the rest of the column, so the deformation and velocity profile through the ice sheet depends strongly on the flow properties of the basal ice. The flow properties of the basal ice become more important if the debris-laden ice flows much more readily than clean ice because the higher deformation rates would be significant for the movement of the ice mass and might be difficult to distinguish from high sliding rates (Johnsen and Dansgaard, 1992; Dansgaard and others, 1993; Castelnau and others, 1998). If, on the other hand, the flow rates are less than for clean ice, the dependence on the flow properties of basal ice will not be so severe and the flow profile will resemble a gradual approach to the zero deformation of the bed.

There are several previous works concerning the flow of debris-laden ice, some reporting enhanced flow. Some studies have reported on mechanical experiments (Shoji and Langway, 1984; Lawson, 1996; Fitzsimons and others, 1999). Others are based on structural properties of glacial ice, in which the impurity content is relatively low (Holdsworth and Bull, 1970; Anderton, 1973; Fisher and Koerner, 1986; Echelmeyer and Wang, 1987; Tison and others, 1993, 1994;

\footnotetext{
* Present address: NASA Goddard Space Flight Center, Code 971, Greenbelt, MD 20771, U.S.A.
}

Gow and Meese, 1996). These reports have suggested that debris-laden ice exhibits enhanced flow (i.e. higher strain rates). For higher concentrations of impurities, lower strain rates are inferred by Butkovich and Landauer (1959) and Nickling and Bennett (1984). It should be noted that in these field situations it is not clear to what extent other factors such as the inhomogeneity of the stress field or the anisotropy of the debris-laden ice may also be relevant.

There are extensive results available on relative strengths of frozen soil (Vyalov and others, 1962; Wijeweera and Joshi, 1993; Fish, 1994). However, there is much less material covering the steady-state creep of frozen soil or debris-laden ice with low impurity content at the low shear stresses which prevail in ice sheets. The basal shear stresses in glaciers and ice sheets are most commonly in the range $0.05-0.20 \mathrm{MPa}$. We are therefore particularly interested in the flow properties of debris-laden ice over this range. At these low stresses it takes considerable time for laboratory-made randomly oriented polycrystalline ice to reach minimum strain rate (at about $1 \%$ strain) and much longer to reach a steady-state tertiary strain rate (at $>10 \%$ strain). In ice sheets and glaciers, large strains can be expected to prevail. We therefore need laboratory strain rates to also reach these large strains.

Other measurements of the creep-rate dependence of ice on debris content have not provided a clear relation between these two factors. Hooke and others (1972) studied sand contents from $0 \%$ to $\sim 35 \%$ by volume under $0.56 \mathrm{MPa}$ compression (0.26 MPa octahedral shear stress) at $-9.1^{\circ} \mathrm{C}$. Considerable variation was found for concentrations less than $10 \%$ sand volume. For higher sand concentrations, a clear and strong decreasing trend in creep rate occurred to less than $10 \%$ of the clean-ice creep rate by $35 \%$ volume sand concentration.

Nayar (1966) and Nayar and others (1971) studied ice with finely dispersed silica in the concentration range $0-1 \%$ by 
volume. The tests were in simple compression over the range 0.2-0.9 MPa octahedral at temperatures from $-2^{\circ}$ to $-22^{\circ} \mathrm{C}$. A strong decrease in creep rate with impurity concentration was obtained.

Baker and Gerberich (1979) studied ice samples with sand volume concentrations of $0-6 \%$ in simple compression at $\sim 0.5 \mathrm{MPa}(0.26 \mathrm{MPa}$ octahedral $)$ at various temperatures between $-5^{\circ}$ and $-38^{\circ} \mathrm{C}$. They also attempted to determine if the crystal size of the ice was relevant to the creep rate. For the present context, considering the dependence on sand concentration alone, they obtained little difference in creep rate relative to that of clean ice for low concentrations (up to $2 \%$ by volume). But they did find increased creep rates by a factor of about 1.8 for the range of concentrations $5-7 \%$ sand volume.

Nickling and Bennett (1984) performed shear experiments on two samples retrieved from rock glaciers in Grizzly Creek, Yukon Territory, Canada. Their shear experiments were run at $-1{ }^{\circ} \mathrm{C}$, with sand contents ranging from $0 \%$ to near $100 \%$ volume and a constant loading rate of $9.63 \times 10^{-4}$ $\mathrm{cm} \mathrm{min}^{-1}$. Results indicated that samples with higher sand content were subject to less interlocking than samples with lower sand content. The stress-strain curves for the $75 \%$ and $70 \%$ sand-content samples, though, resulted in more "regular" curves indicating that the particle interlocking of these samples was not as evident. Additionally, the sample shear strength increased as the sand content was increased.

Lawson (1996) conducted uniaxial compression tests on debris-laden field ice from Taylor Glacier, Antarctica, (5$50 \%$ sand content) and on clean ice. The tests were performed at temperatures ranging from $0^{\circ}$ to $-25^{\circ} \mathrm{C}$ and with uniaxial compression strength of $1.1-7.6 \mathrm{MPa}$ for debrisladen ice and 1.9-3.4 MPa for clean ice. The strain rates for the tests ranged from $10^{-2}$ to $10^{-3} \mathrm{~s}^{-1}$. Lawson observed that at high temperatures between $0^{\circ}$ and $-5^{\circ} \mathrm{C}$, pressure melting was the dominant deformation mechanism in the debrisladen ice, while cracking was the dominant deformation mechanism in clean ice. But at temperatures of $-25^{\circ} \mathrm{C}$, the debris-laden ice reached higher strengths than the clean glacier ice, and cracking was the dominant deformation mechanism in both ice types.

\section{EXPERIMENTAL TEGHNIQUE}

Laboratory-prepared clean and sand-laden ice was prepared by a method similar to that proposed by Jacka and Lile (1984). Glean samples were included to provide control results against which results for sand-laden ice are compared. For the sand-laden samples, finely ground ice particles were mixed with cold mortar sand in approximately the required proportions before placing in a mould to which water at freezing point was added. The exact concentration of the sand was determined after each experiment, by weighing the residual sand after melting the sample. Mortar sand was used because it contains a range of particle sizes from typically coarse quartz sand $(0.25-2.0 \mathrm{~mm}$ diameter grains) to silty mud with particle sizes $<0.05 \mathrm{~mm}$. The sand particle-size distributions were strongly bimodal, centred around these two grades but with the coarse sand dominating. The concentration of silt to the total impurity amount was very variable but averaged about $15 \%$ for the sandy samples. This mix of sand and silt is not unlike the material found in the basal ice cores (Holdsworth and Bull,
Table 1. Summary of test results in uniaxial compression (constant load), simple shear (constant stress) and uniaxial compression (constant strain rate), over the temperature range $-0.20^{\circ}$ to $-18.0^{\circ} \mathrm{C}$

\begin{tabular}{|c|c|c|c|c|c|}
\hline \multirow[t]{2}{*}{ Sample } & Sand content & Stress & Temperature & $\begin{array}{l}\text { Minimum } \\
\text { strain rate }\end{array}$ & $\begin{array}{c}\text { Tertiary } \\
\text { strain rate }\end{array}$ \\
\hline & $\%$ volume & $\mathrm{MPa}$ & ${ }^{\circ} \mathrm{C}$ & $\mathrm{s}^{-1}$ & $s^{-1}$ \\
\hline $1, \mathrm{C}_{\mathrm{l}}$ & 0 & 0.13 & $-18.0 \pm 0.5$ & $3.5 \times 10^{-10}$ & \\
\hline $2, \mathrm{C}_{1}$ & 0.7 & 0.13 & $-18.0 \pm 0.5$ & $4.1 \times 10^{-10}$ & \\
\hline $3, \mathrm{C}_{1}$ & 1.0 & 0.13 & $-18.0 \pm 0.5$ & $3.7 \times 10^{-10}$ & \\
\hline $4, \mathrm{C}_{1}$ & 4.8 & 0.13 & $-18.0 \pm 0.5$ & $3.1 \times 10^{-10}$ & \\
\hline $5, \mathrm{C}_{1}$ & 14.5 & 0.13 & $-18.0 \pm 0.5$ & $3.3 \times 10^{-10}$ & \\
\hline $6, \mathrm{C}_{2}$ & 0 & 0.5 & $-13.0 \pm 0.5$ & $3.2 \times 10^{-8}$ & $1.0 \times 10^{-7}$ \\
\hline $7, \mathrm{C}_{2}$ & 0.8 & 0.5 & $-13.0 \pm 0.5$ & $3.3 \times 10^{-8}$ & $9.5 \times 10^{-8}$ \\
\hline $8, \mathrm{C}_{2}$ & 0 & 0.2 & $-2.0 \pm 0.1$ & $1.8 \times 10^{-8}$ & \\
\hline $9, \mathrm{C}_{2}$ & 0.8 & 0.2 & $-2.0 \pm 0.1$ & $1.6 \times 10^{-8}$ & \\
\hline $10, \mathrm{~S}_{1}$ & 0 & 0.4 & $-13.0 \pm 0.5$ & $2.5 \times 10^{-8}$ & $2.1 \times 10^{-7}$ \\
\hline $11, \mathrm{~S}_{1}$ & 0.8 & 0.4 & $-13.0 \pm 0.5$ & $2.4 \times 10^{-8}$ & $2.0 \times 10^{-7}$ \\
\hline $12, \mathrm{~S}_{1}$ & 0 & 0.2 & $-2.0 \pm 0.1$ & $3.0 \times 10^{-8}$ & $4.0 \times 10^{-7}$ \\
\hline $13, \mathrm{~S}_{1}$ & 0.8 & 0.2 & $-2.0 \pm 0.1$ & $2.1 \times 10^{-8}$ & $2.9 \times 10^{-7}$ \\
\hline $14, \mathrm{~S}_{1}$ & 0 & 0.2 & $-0.20 \pm 0.01$ & $7.0 \times 10^{-8}$ & $4.0 \times 10^{-7}$ \\
\hline $15, \mathrm{~S}_{1}$ & 0.8 & 0.2 & $-0.20 \pm 0.01$ & $5.5 \times 10^{-8}$ & $3.5 \times 10^{-7}$ \\
\hline \multirow[t]{2}{*}{ Sample } & Sand content & rield stress & Temperature & $\begin{array}{l}\text { Constant } \\
\text { strain rate }\end{array}$ & $\begin{array}{c}\text { Tertiary } \\
\text { stress }\end{array}$ \\
\hline & $\%$ volume & $\mathrm{MPa}$ & ${ }^{\circ} \mathrm{C}$ & $\mathrm{s}^{-1}$ & $\mathrm{MPa}$ \\
\hline $16, \mathrm{C}_{3}$ & 0 & 2.19 & $-15.0 \pm 0.1$ & $6.0 \times 10^{-3}$ & 1.46 \\
\hline $17, \mathrm{C}_{3}$ & 0 & 2.19 & $-15.0 \pm 0.1$ & $6.0 \times 10^{-3}$ & 1.56 \\
\hline $18, \mathrm{C}_{3}$ & 0 & 2.28 & $-15.0 \pm 0.1$ & $6.0 \times 10^{-3}$ & 1.36 \\
\hline $19, \mathrm{C}_{3}$ & 0 & 1.40 & $-15.0 \pm 0.1$ & $6.0 \times 10^{-3}$ & 1.25 \\
\hline $20, \mathrm{C}_{3}$ & 0 & 1.44 & $-15.0 \pm 0.1$ & $6.0 \times 10^{-3}$ & 0.88 \\
\hline $21, \mathrm{C}_{3}$ & 0 & 2.61 & $-15.0 \pm 0.1$ & $6.0 \times 10^{-3}$ & 2.45 \\
\hline $22, \mathrm{C}_{3}$ & 0 & 1.25 & $-15.0 \pm 0.1$ & $6.0 \times 10^{-3}$ & 0.56 \\
\hline $23, \mathrm{C}_{3}$ & 0 & 1.41 & $-15.0 \pm 0.1$ & $6.0 \times 10^{-3}$ & 0.59 \\
\hline $24, \mathrm{C}_{3}$ & 0 & 1.34 & $-15.0 \pm 0.1$ & $6.0 \times 10^{-3}$ & 0.53 \\
\hline $25, \mathrm{C}_{3}$ & 0 & 1.99 & $-15.0 \pm 0.1$ & $6.0 \times 10^{-3}$ & 1.18 \\
\hline $26, \mathrm{C}_{3}$ & 0.14 & 2.14 & $-15.0 \pm 0.1$ & $6.0 \times 10^{-3}$ & 1.41 \\
\hline $27, \mathrm{C}_{3}$ & 0.55 & 1.89 & $-15.0 \pm 0.1$ & $6.0 \times 10^{-3}$ & 0.91 \\
\hline $28, \mathrm{C}_{3}$ & 0.57 & 2.47 & $-15.0 \pm 0.1$ & $6.0 \times 10^{-3}$ & 1.40 \\
\hline $29, \mathrm{C}_{3}$ & 0.84 & 2.55 & $-15.0 \pm 0.1$ & $6.0 \times 10^{-3}$ & 1.84 \\
\hline $30, \mathrm{C}_{3}$ & 1.36 & 2.22 & $-15.0 \pm 0.1$ & $6.0 \times 10^{-3}$ & 1.78 \\
\hline
\end{tabular}

1970; Anderton, 1974; Gow and others, 1979; Herron and Langway, 1979; Gunderstrup and Hansen, 1984; Hammer and others, 1985).

In this paper, we present results of deformation tests in constant-load uniaxial compression (samples in group $\mathrm{C}_{1}$ and $\mathrm{C}_{2}$ of Table 1 ), constant-strain-rate uniaxial compression (samples in group $\mathrm{C}_{3}$ of Table 1 ) and constant-stress simple shear (group $\mathrm{S}_{1}$ of Table 1). Figure 1 shows creep curves for each test from groups $\mathrm{C}_{1}, \mathrm{C}_{2}$ and $\mathrm{S}_{1}$. The test samples for compression tests were cylinders of $25 \mathrm{~mm}$ (groups $\mathrm{C}_{1}, \mathrm{C}_{2}$ ) and $50 \mathrm{~mm}$ (group $\mathrm{C}_{3}$ ) diameter. Sample lengths were $60 \mathrm{~mm}$ (groups $\mathrm{C}_{1}, \mathrm{C}_{2}$ ) and $\sim 100 \mathrm{~mm}$ (group $\mathrm{C}_{3}$ ). Dimensions (length $\times$ width $\times$ height) of shear test samples (group $\mathrm{S}_{1}$ ) were $95 \mathrm{~mm} \times 15 \mathrm{~mm} \times 16 \mathrm{~mm}$. At test commencement, shear samples had a $30^{\circ}$ back cut so that at $\sim 1-10 \%$ strain, deformation of the sample was such that there was no vertical displacement, i.e. simple shear ( $\mathrm{Li}$ and others, 2000).

The deformation apparatus for constant-load uniaxial compression tests has been described by Jacka and Lile (1984). The shear apparatus is described by $\mathrm{Li}$ and others (2000). The constant-strain-rate deformation apparatus is a Monsanto horizontal screw-driven universal testing 

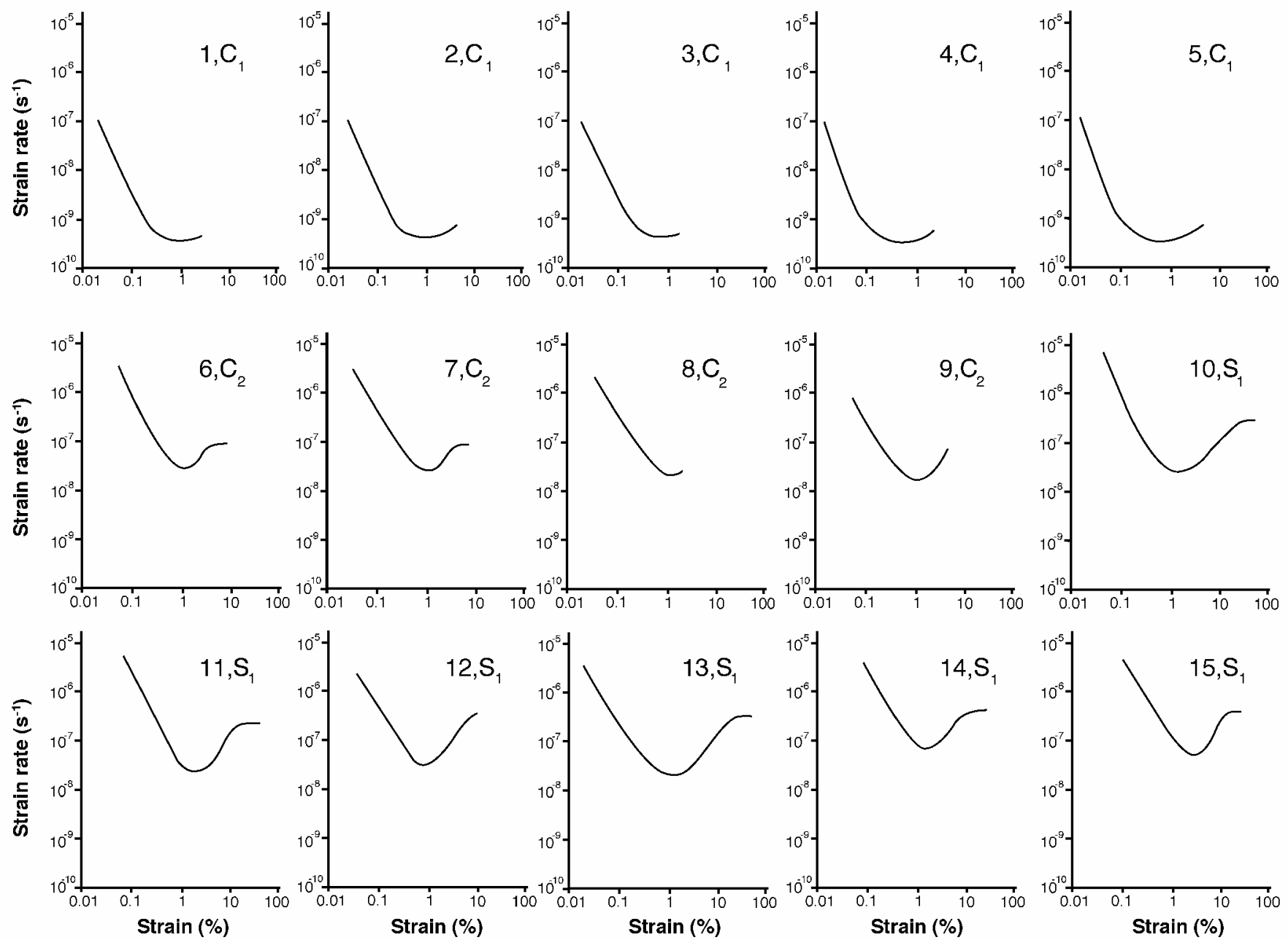

Fig. 1. Creep curves (plots of octahedral strain rate as a function of octahedral strain) for each of the tests in compression (labelled $C_{7}$ and $C_{2}$ and shear (labelled $\left.S_{1}\right)$ under constant load. Temperature, stress, debris content and other details are provided in Table 1.

machine that is able to apply a continually increasing load (maximum $20 \mathrm{kN}$ ) at fixed values of constant cross-head speed in the range $0.003-0.870 \mathrm{~mm} \mathrm{~s}^{-1}$.

Stresses and strain rates used throughout this paper are octahedral (root mean square of the tensor deviators) values so that, at minimum strain rate (constant stress) or yield stress (constant strain rate), results in compression and shear are directly comparable (Li and others, 1996). Other properties of the tests are listed in Table 1.

\section{RESULTS}

\section{Group $\mathrm{C}_{1}$}

In most of the laboratory tests of other workers so far carried out on debris-laden ice, there has been no clear evidence to show that similar creep curves or clear minimum creep rates were attained. Creep rates need to be compared at comparable total strains or at similar stages of the creep curves. The objective of the tests of group $\mathrm{G}_{1}$ was to examine the creep rate carefully through to comparable large strains for all tests. The stress chosen, $0.13 \mathrm{MPa}$ octahedral in uniaxial compression, was meant to be realistic for comparison with the basal shear stresses typical of glaciers and ice sheets. The sand concentrations were selected to cover the lower end of the range up to $15 \%$ by volume. The temperature, $-18{ }^{\circ} \mathrm{C}$, was the first in a series of tests aimed at covering a wide range of temperatures. These tests were run, typically to a strain of $4-6 \%$, until a minimum flow rate had clearly been attained. Some of these tests took $>1.8$ years ( $>16000$ hours) to attain this strain.

From Table 1, the close similarity in minimum strain rate between the five samples is remarkable (mean minimum strain rate is $3.54 \times 10^{-10} \mathrm{~s}^{-1}$ ), and there is no relationship apparent between the very minor differences in minimum strain rate with sand content. There is little support here for any strong dependence of creep rate on debris content over this range of concentration $(0-14.5 \%$ by volume). The measurements here are for a lower stress than previously reported results, but this lower stress is more relevant to the flow of polar ice masses.

\section{Group $\mathrm{C}_{2}$}

While these experiments include only $0.8 \%$ volume sand concentration, they have been continued to strains sufficient in some cases to attain tertiary strain rate. It is seen from Table 1 that the minimum strain rates for clean ice and sandladen ice are close to identical. At $0.5 \mathrm{MPa}$ and $-13^{\circ} \mathrm{C}$ the tertiary creep rates are also very similar (samples 6 and 7).

\section{Group $S_{1}$}

The sand content for the shear tests also is $0.8 \%$. All shear tests were carried out at $0.2 \mathrm{MPa}$, while three different temperatures, $-13^{\circ},-2.0^{\circ}$ and $-0.20^{\circ} \mathrm{C}$, were examined. For all three temperatures, even at $-0.20^{\circ} \mathrm{C}$, the minimum and 
tertiary creep rates appear unaffected (e.g. tertiary strain rates of $4.0 \times 10^{-7} \mathrm{~s}^{-1}$ for clean ice compared with $3.5 \times 10^{-7}$ $\mathrm{s}^{-1}$ for sand-laden ice) by $0.8 \%$ volume sand content.

As an aside, it is worth noting that the enhancement of tertiary flow rate over minimum flow rate for the compression tests $\left(\mathrm{C}_{2}\right)$ above was $\sim 3$ and that for the shear tests $\left(\mathrm{S}_{1}\right)$ it was $\sim 9$ for both the sand-laden samples and the clean samples. These values are similar to those found in the ice-mechanics literature for anisotropic ice in easy glide in compression and simple shear, respectively (e.g. Li and others, 1996).

\section{Group $\mathrm{C}_{3}$}

There appears to be a high degree of scatter in the constantstrain-rate results, and further, more careful examination may be required with the constant-strain-rate apparatus, in particular to examine the effect of debris on ice deformation at higher strain rates. The mean yield stress for the ten clean samples of group $\mathrm{C}_{3}$ (samples $\left.16-25\right)$ is $1.81 \pm 0.49 \mathrm{MPa}$. The yield stresses for the five sand-laden samples (samples 26-30) are higher than this, but there is no clear trend of increasing yield stress with sand content. The tertiary stress values for the sand-laden samples are also higher than the mean value $(1.18 \pm 0.59 \mathrm{MPa})$ for the ten clean samples. With one exception (sample 27), the tertiary stress also increases systematically with sand content. There is some evidence from these results, therefore, that at this strain rate $\left(10^{-3} \mathrm{~s}^{-1}\right)$ and at this temperature $\left(-15^{\circ} \mathrm{C}\right)$ sand concentrations in the ice may tend to harden the ice, perhaps acting as a reinforcing agent within the ice. This result would seem to confirm Lawson's (1996) result in the same strain-rate range as examined here, that at temperatures of $-25^{\circ} \mathrm{C}$ the debris-laden ice reached higher strengths than the clean glacier ice.

\section{GONGLUSIONS}

Our laboratory results present evidence of no significant dependence of either minimum or tertiary flow rate on sand content (up to $15 \%$ volume) within ice under deformation in the stress range $0.13-0.5 \mathrm{MPa}$ and temperature range -0.02 to $-18.0^{\circ} \mathrm{C}$. The laboratory tests have included both uniaxial compression and simple shear. These stress patterns and, importantly, the temperature and stress ranges we have examined are similar to those found at the base of the polar ice sheets.

This contrasts with some laboratory studies of other workers, generally at higher stresses, showing more variable results of both higher and lower strain rates compared with those for clean ice. Our results at higher stresses (and constant strain rate) also provided some indication that sandladen ice is harder under these conditions, at least at $-15^{\circ} \mathrm{C}$. This result is of little relevance, however, to the flow of the polar ice sheets and mountain glaciers.

It is also important to examine the creep dependence on the type of solid impurity and whether inherent chemical effects with the impurities are also relevant. The change of the ice crystallographic properties through the course of the deformation for debris-laden ice should also be studied for comparison with the general results obtained for clean ice.

Caution is required in any assumptions about the flow rates of debris-laden ice in ice masses until a clearer understanding of the debris-laden ice-flow rates relative to those for clean ice has been obtained. To facilitate such an understanding, samples of debris-laden ice from field situations need to be studied in the laboratory under the same type of stress magnitude and configuration as exists in situ in field conditions. Comparisons need to be made with clean ice deformed to high strains under the same stress configuration, and adequate account then needs to be taken of other factors such as the crystallography and the development of anisotropy. This work is now in progress at the Antarctic CRG.

\section{REFERENCES}

Anderton, P.W. 1973. Structural glaciology of a glacier confluence, Kaskawulsh Glacier, Yukon Territory, Canada. Ohio State Univ. Inst. Polar Stud. Rep. 26.

Anderton, P.W. 1974. Ice fabrics and petrography, Meserve Glacier, Antarctica. f. Glaciol., 13(68), 285-306.

Baker, R.W. and W.W. Gerberich. 1979. The effect of crystal size and dispersed-solid inclusions on the activation energy for creep of ice. F. Glaciol., 24(90), 179-194.

Butkovich, T. R. and J. K. Landauer. 1959. The flow law for ice. SIPRE Res. Rep. 56.

Castelnau, O. and 7 others. 1998. Anisotropic behavior of GRIP ices and flow in central Greenland. Earth Planet. Sci. Lett., 154(1-4), 307-322.

Dansgaard, W. and 10 others. 1993. Evidence for general instability of past climate from a 250-kyr ice-core record. Nature, 364(6434), 218-220.

Echelmeyer, K. and Wang Zhongxiang. 1987. Direct observation of basa sliding and deformation of basal drift at sub-freezing temperatures. $\mathcal{F}$. Glaciol., 33(113), 83-98.

Fish, A. M. 1994. Creep and strength of frozen soil under triaxial compression. CRREL Spec. Rep. 94-32.

Fisher, D. A. and R. M. Koerner. 1986. On the special rheological properties of ancient microparticle-laden Northern Hemisphere ice as derived from bore-hole and core measurements. F. Glaciol., 32(112), 501-510.

Fitzsimons, S. J., K. J. McManus and R. D. Lorrain. 1999. Structure and strength of basal ice and substrate of a dry-based glacier: evidence for substrate deformation at sub-freezing temperatures. Ann. Glaciol., 28, $236-240$.

Gow, A. J. and D. A. Meese. 1996. Nature of basal debris in the GISP2 and Byrd ice cores and its relevance to bed processes. Ann. Glaciol., 22, 134-140.

Gow, A. J., S. Epstein and W. Sheehy. 1979. On the origin of stratified debris in ice cores from the bottom of the Antarctic ice sheet. F. Glaciol., 23(89), 185-192.

Gundestrup, N. S. and B. L. Hansen. 1984. Bore-hole survey at Dye 3, south Greenland. F. Glaciol., 30(106), 282-288.

Hammer, C. U., H. B. Clausen, W. Dansgaard, A. Neftel, P. Kristinsdóttir and E. Johnson. 1985. Continuous impurity analysis along the Dye 3 deep core. In Langway, C. C., Jr, H. Oeschger and W. Dansgaard, eds. Greenland ice core: geophysics, geochemistry, and the environment. Washington, DC, American Geophysical Union, 90-94. (Geophysical Monograph 33.)

Herron, S. and C. G. Langway, Jr. 1979. The debris-laden ice at the bottom of the Greenland ice sheet. F. Glaciol., 23(89), 193-207.

Holdsworth, G. and C. Bull. 1970. The flow of cold ice: investigations on Meserve Glacier, Antarctic. International Association of Scientific Hydrology Publication 86 (Symposium at Hanover 1968-Antarctic Glaciological Exploration (ISAGE)), 204-216.

Hooke, R. LeB., B. B. Dahlin and M. T. Kauper. 1972. Creep of ice containing dispersed fine sand. F. Glaciol., 11(63), 327-336.

Jacka, T. H. and R. C. Lile. 1984. Sample preparation techniques and compression apparatus for ice flow studies. Cold Reg. Sci. Technol., 8 (3), 235-240.

Johnsen, S. J. and W. Dansgaard. 1992. On flow model dating of stable isotope records from Greenland ice cores. In Bard, E. and W. S. Broecker, eds. The last deglaciation: absolute and radiocarbon chronologies. Berlin, etc., SpringerVerlag, 13-24. (NATO ASI Series I: Global Environmental Change 2.)

Lawson, W. 1996. The relative strengths of debris-laden basal ice and clean glacier ice: some evidence from Taylor Glacier, Antarctica. Ann. Glaciol., 23, 270-276

Li Jun, T. H. Jacka and W. F. Budd. 1996. Deformation rates in combined compression and shear for ice which is initially isotropic and after the development of strong anisotropy. Ann. Glaciol., 23, 247-252.

Li Jun, T. H. Jacka and W. F. Budd. 2000. Strong single-maximum crystal fabrics developed in ice undergoing shear with unconstrained normal deformation. Ann. Glaciol., 30, 88-92.

Nayar, H. S. 1966. Creep behaviour of pure ice and ice dispersed with ultrafine amorphous silica $\left(\mathrm{SiO}_{2}\right)$ particles. (Ph.D. thesis, Rensselaer Polytechnic Institute, New York.)

Nayar, H. S., F.V. Lenel and G. S. Ansell. 1971. Creep of dispersions of ultrafine amorphous silica. 7. Appl. Phys., 42(10), 3786-3789. 
Nickling, W. G. and L. Bennett. 1984. The shear strength characteristics of frozen coarse granular debris. F. Glaciol., 30(106), 348-357.

Shoji, H. and C. C. Langway, Jr. 1984. Flow behavior of basal ice as related to modeling considerations. Ann. Glaciol., 5, 141-148.

Tison, J.-L., J.-R. Petit, J.-M. Barnola and W. C. Mahaney. 1993. Debris entrainment at the ice-bedrock interface in sub-freezing temperature conditions (Terre Adélie, Antarctica). F. Glaciol., 39(132), 303-315.
Tison, J.-L., T. Thorsteinsson, R.D. Lorrain and J. Kipfstuhl. 1994. Origin and development of textures and fabrics in basal ice at Summit, central Greenland. Earth Planet. Sci. Lett., 125(3-4), 421-437.

Vyalov, S. S. and 6 others. 1962. Prochnost' i polzuchest' merzlykh gruntov $i$ raschety ledogruntorykh ograzhdeniy [ The stability and creep of frozen ground and calculations of ground-ice enclosures 7. Moscow, Izd-vo Akademii Nauk SSSR. Akademiya Nauk SSSR. Institut Merzlovedeniya.

Wijeweera, H. and R. C. Joshi. 1993. Creep behaviour of saline fine-grained frozen soil. ASCE 7. Cold Reg. Engin., 7(3), 77-89. 